Psammobia tellinella, Lamarck. Dredged in Dalkey Sound.

Tellina pygmaa, Philippi. Same locality as the last.

Cytherea Chione. One valve : dredged in about 14 fathoms, Dalkey Sound.

Circe minima, Montagu. Two odd valves : same locality as the last. Astarte sulcata, Da Costa. Same locality as the last.

Cardium nodosum, Turton. Same locality.

C. fasciatum, Montagu. Same locality.

Lucina spinifera, Montagu. Trawled off the Calf of Man.

Leda caudata, Donovan. Two live specimens with some odd valves dredged in 13 fathoms, Dalkey Sound.

Lima Loscombii, Sowerby. Dredged in a live state from 12 to 14 fathoms, Dalkey Sound.

Lima hians, Gmelin. A beautiful live specimen was dredged last month in Killiney Bay in about 15 fathoms.

Anomia striata ?, Lovén. Dredged in Dalkey Sound.

Chiton lavis, Pennant. Same locality.

Trochus exiguus?, Pulteney. South Bull, Dublin Bay.

T. granulatus, Born. Trawled off the Calf of Man.

T. Montagui, Gray. Dredged in from 12 to 14 fathoms, Dalkey Sound.

Fusus propinquus, Alder. Trawled off the Skerries; but I have obtained much better specimens last summer off the Saltees.

Mangelia gracilis, Montagu. Trawled off Skerries, in company with M. turricula, Trophon clathratus and Nassa incrassata.

Yours truly obliged,

William White Walpole.

\title{
On the Sun Column as seen at Sandwick Manse, Orkney, in April 1852. By C. Clouston.
}

The perpendicular column of light which appeared repeatedly at sunset and sunrise during April, deserves a more particular account than the usual monthly report contains, as this is the most northern locality in which I have yet heard of its appearance.

When seen in the evening. it was generalls immediately-after the 
It had periods of greater and less brightness, but for the most part was steady, something like a sunbeam among the clouds, and never had any approach to the rapid motion of the aurora.

Its colour was pale or whitish in its upper portion, or when it appeared contrasted with the dark sky ; but in passing through the red, copper, or orange-coloured sky that prevailed lower down, it partook of its shade, and tinged the thin strata of cloud that lay across it with a brighter hue of their own colour. Fifty-five minutes was the longest period that it was visible any evening. I am told that it also appeared very bright some mornings before sunrise.

If the phænomenon was uncommon, so was the state of the atmosphere when it occurred. The drought was unprecedented; only about $\frac{1}{10}$ th of an inch of rain falling in April, which is about $\frac{1}{20}$ th of the average quantity in that month in previous years. The atmospheric pressure was great, the mercury never being lower than 30.07 , nor higher than 30.32 . The temperature was also high for the month, being $47^{\circ} \cdot 64$, or more than $4^{\circ}$ above the average for April.

The atmosphere was very calm, and the sky near the horizon of that red or copper colour which generally indicates dry and warm weather, so that at last we could anticipate its appearance. I do not presume to explain the mode of its production, but these circumstances may assist others in so doing.

\section{METEOROLOGICAL OBSERVATIONS FOR MAY 1852.}

Chiswick.-May 1. Overcast : cloudy : clear. 2. Cloudy and cold: frosty at night. 3. White clouds : fine : clear and frosty. 4. Dusky clouds : clear and frosty. 5. Densely clouded : clear and frosty at night. 6. Cloudy : clear. 7. Overcast : very fine. 8. Cloudy : fine. 9. Fine. 10. Fine : rain at night. 11. Boisterous, with heavy shower, partly hail. 12. Heavy rain : thunder. 13. Cloudy : overcast : boisterous at night. 14. Showery and boisterous : clear. 15,16. Very fine. 17. Slight drizzle : overcast : thunder, lightning and rain at night. 18. Very fine: rain at night. 19. Very fine. 20. Hazy : fine: showers. 21. Overcast. 22. Cloudy : clear. 23. Cloudy. 24, 25. Overcast : fine. 26. Rain. 27. Overcast. 28. Densely clouded. 29. Rain. 30. Fine: cloudy. 31. Fine : cloudy: clear and cold.

Mean temperature of the month ........................... $51^{\circ} \cdot 45$

Mean temperature of May 1851 ......................... $51 \cdot 16$

Mean temperature of May for the last twenty-six years ... $54 \cdot 07$

Average amount of rain in May ........................... $1.74 \mathrm{inch}$.

Boston.-May 1. Cloudy. 2. Cloudy : rain A.M. 3, 4. Cloudy. 5. Cloudy : rain A.m. 6. Cloudy. 7. Fine. 8. Cloudy. 9, 10. Fine. 11. Cloudy. 1214. Cloudy : rain A.M. 15, 16. Fine. 17. Cloudy. 18. Cloudy : rain A.M. and P.M. 19. Cloudy : rain A.M. 20. Fine. 21. Cloudy : rain A.M. and P.M. 22-25. Cloudy. 26. Cloudy : rain P.м. 27-29. Cloudy. 30. Fine. 31. Cloudy.

Sandwick Manse, Orkney.-May 1. Cloudy : fine. 2. Clear: fine. 3. Cloudy : fine : clear: fine. 4. Cloudy : fine. 5. Drops : fine : cloudy : fine. 6. Clear: fine : cloudy : fine. 7. Drops : rain : clear. 8. Drops: showers. 9. Rain : clear. 10. Drops : clear : aurora. 11. Cloudy : showers. 12. Bright: clear. 13. Rain : clear: fine. 14. Bright: showers. 15. Clear: cloudy. 16. Clear. 17. Clear: fine. 18, 19. Clear : fine : aurora. 20-23. Clear : fine. 24. Bright : fine : clear : fine. 25. Clear: fine. 26. Cloudy. 27. Cloudy : fine. 28. Bright: cloudy : showers. 29. Bright: showers : cloudy : hail-showers. 30. Sleet-showers. 31. Sleet-showers : showers.-This month has been fine, warm and dry.

Mean temperature of May for twenty-five years previous ... $47^{\circ} \cdot 88$

Mean temperature of this month .......................... $50 \cdot 49$

Average quantity of rain in May for six years ............ 1.72 inch. 


\section{$2 \mathrm{BHL}$ Biodiversity Heritage Library}

Clouston, Charles. 1852. "On the sun column as seen at Sandwick Manse, Orkney, in April 1852." The Annals and magazine of natural history; zoology, botany, and geology 10, 78-79. https://doi.org/10.1080/03745485609495636.

View This Item Online: $\underline{\text { https://www.biodiversitylibrary.org/item/19400 }}$

DOI: https://doi.org/10.1080/03745485609495636

Permalink: https://www.biodiversitylibrary.org/partpdf/10682

\section{Holding Institution}

Natural History Museum Library, London

\section{Sponsored by}

Natural History Museum Library, London

\section{Copyright \& Reuse}

Copyright Status: Public domain. The BHL considers that this work is no longer under copyright protection.

This document was created from content at the Biodiversity Heritage Library, the world's largest open access digital library for biodiversity literature and archives. Visit BHL at https://www.biodiversitylibrary.org. 